\title{
Peran Vicarious Liability Dalam Pertanggungjawaban Korporasi (Studi Terhadap Kejahatan Korupsi Yang Dilakukan Oleh Kader Partai Politik)
}

\author{
Muhammad Isra Mahmud \\ Fakultas Hukum Universitas Islam Indonesia Yogyakarta Indonesia \\ Jln. Cik Di Tiro No. 1, Yogyakarta, Indonesia 55223 \\ m.isramahmud@gmail.com
}

\begin{abstract}
This study aims to identify and analyze: first, the position of political parties as private law subjects; second, the role of vicarious liability in the effort to convict legal entities of political parties. The research method used is normative juridical with a statutory approach. This study concludes that first, political parties as legal entities which are also legal subjects can be held accountable for acts of human rights violations, based on the theories and formulations of the laws and regulations that have been regulated in the Republic of Indonesia. Second, vicarious liability plays a role in efforts to punish legal entities such as political parties in the form of fines or additional penalties, which in practice experience difficulties or weaknesses.
\end{abstract}

Key Words: Corruption, criminal liability of political parties, substitutive punishment

\begin{abstract}
Abstrak
Penelitian ini bertujuan untuk mengetahui dan menganalisis: pertama, kedudukan partai politik sebagai subjek hukum privat; kedua, peran vicarious liability dalam upaya pemidanaan badan hukum partai politik. Metode Penelitian yang digunakan adalah penelitian yuridis normatif dengan pendekatan perundang-undangan. Penelitian ini menyimpulkan, pertama, partai politik selaku badan hukum yang juga merupakan subjek hukum dapat dipertanggungjawabkan atas tindakan pelangaran Hak Asasi Manusia, dengan di dasari pada teori-teori dan formulasi dari Peraturan Perundang-Undangan yang telah diatur dalam Republik Indonesia. Kedua, vicarious liability berperan dalam upaya pemidanaan badan hukum seperti Partai Politik berupa pidana denda atau tambahan, yang mana dalam tataran praktik mendapatkan kesulitan atau kelemahan.
\end{abstract}

Kata-kata Kunci: Pertanggungjawban pidana partai politik, tindak pidana korupsi, pidana pengganti. 


\section{Pendahuluan}

Korupsi adalah fenomena hidup manusia. Hampir seluruh rumpun bahasa memiliki istilah yang mempersentasikan makna kecurangan atau korupsi atau paling tidak mengadopsi istilah tertentu yang memiliki arti sepadan. Banyak literatur menyatakan korupsi berasal dari kata Latin corruptie atau corruptus. Terdapat istilah lain yaitu corruption yang berasal dari Bahasa Latin kuno corrumpore. Istilah tersebut kemudian berkembang dalam Bahasa lain di dunia, seperti corruption atau corrupt (Inggris) dan corruptie/korruptie (Belanda). Corruption sendiri berarti penyuapan sementara corrumpore memiliki makna merusak, yang dalam ensiklopedia Indonesia diterangkan sebagai penyalahgunaan kekuasaan sehingga terjadi penyuapan, pemalsuan serta ketidak beresan lain. ${ }^{1}$ Korupsi terjadi jika tiga hal terpenuhi yaitu (1) seseorang memiliki kekuasaan termasuk untuk menentukan kebijakan publik dan melakukan administrasi kebijakan tersebut; (2) adanya economic rents, yaitu manfaat ekonomi yang ada sebagai akibat kebijakan publik tersebut, dan (3) sistem yang ada membuka peluang terjadinya pelanggaran oleh pejabat publik yang bersangkutan. ${ }^{2}$

Relasi partai politik dan korupsi pada masa ini menunjukan heterogenitas pandangan yang disinyalir menimbulkan paradigma buruk di kalangan masyarakat. Belum luput dari ingatan publik yang dikecewakan atas partai politik yang mencalonkan eks napi koruptor yang maju kembali pada Pemilihan Legislatif 2019. Selanjutnya publik kembali dikecewakan dengan adanya Operasi Tangkap Tangan (OTT) oleh Komisi Pemberantasan Korupsi (KPK) terhadap Ketua Umum PPP Romahurmuziy yang akhirnya di adili dalam kasus suap JualBeli jabatan di Kementrian Agama (Kemenag). Jeratan kasus Korupsi pada Romahurmuziy seakan mengigatkan kita pada sosok Ketua Umum Golkar 20162017 (Setya Novanto), Ketua Umum PPP 2007-2014 (Surya Darma Ali), Ketua Umum Partai Demokrat 2009-2014 (Anas Urbaningrum), dan Presiden PKS 20092014 (Lutfi Hasan Ishaaq). Mereka semua adalah politisi yang pernah terjerat kasus korupsi saat menjabat ketua Partai. ${ }^{3}$

Adanya bentuk mahar politik yang terjadi dikalangan partai politik menjadi persoalan mendasar lahirnya kader-kader korupsi dalam kontestasi politik Indonesia. Politik kotor yang berujung permintaan uang terhadap kandidat yang diusung mendorong praktik korupsi yang bertujuan mengembalikan mahar

1 Eko Riyadi dkk, Korupsi Sebagai Pelanggaran Hak Asasi Manusia Tawaran Prespektif, PUSHAM UII, Yogyakarta, 2019, hlm. 30.

2 Wijayanto \& Ridwan Zachrie, Korupsi Mengeropsi Indonesia, Sebab, Akibat, dan Prospek Pemberantasan, Gramedia Pustaka Utama, Jakarta, 2009, hlm. 6.

3 https://news.detik.com/kolom/d-4475908/ironi-partai-politik-dalam-pusaran-korupsi. Diakses pada 2 November 2020. 
politik para pemodal penyandang dana. Bentuk pengembalian sangat beragam, mulai dari bagi-bagi proyek yang di danai oleh APBD sampai gratifikasi pengurusan Izin Usaha yang pada akhirnya berujung korupsi. ${ }^{4}$

Pada era sekarang masih banyak negara yang hanya menerapkan sanksi perdata dan administrasi terhadap korupsi sedangkan pertanggungjawaban pidananya tetap kontroversial. Hal ini berkaitan dengan efisiensi pemidanaan dan konsisten terhadap asas-asas hukum pidana (universitas delinquere non potets). Misalnya saja Jerman yang tetap tidak mengatur pertanggungjawaban pidana korporasi, tetapi mengunakan pertanggungjawaban hukum administratif terhadap kesalahan korporasi (Administrative Offence Act). Korporasi tetap dianggap "lack of capacity to act, lack of culpa bility, and inappropriateness of criminal sanction" karena dianggap tidak memiliki badan dan jiwa.

Untuk itu berbagai teori, pendekatan atau model dikembangkan guna memberikan pembenaran terhadap pertanggungjawaban pidana korporasi yang dianggap menyimpang dari pemikiran awal bahan yang memiliki "judicial capacity" hanyalah manusia alamiah (natural person) sehingga tiga permasalahan pokok hukum pidana (actus reus, mens rea, dan sanksi hukum pidana) didesain hanya untuk manusia alamiah. Contoh teori "vicarious liability", teori "strict liability", teori agregrasi, teori identifikasi (alter ego theory), teori delegasi, teori kepelakuan fungsional, teori budaya korporasi, dan "legal reality model'. 5

\section{Rumusan Masalah}

Berdasarkan latar belakang masalah yang diuraikan di atas, maka rumusan masalah dalam penelitian ini sebagai berikut. Pertama, apakah partai politik sebagai badan hukum privat dapat di jadikan sebagai subjek hukum? Kedua, bagaimana peran vicarious criminal liability dalam pertanggungjawaban pidana korporasi partai politik?

\section{Tujuan Penelitian}

Penelitian ilmiah ini bertujuan untuk mengetahui dan menganalisis beberapa pokok permasalahan yaitu: pertama, kedudukan partai politik sebagai badan hukum privat yang dapat dijadikan sebagai subjek hukum. Kedua, peran vacirious liability dalam upaya pemidanaan badan hukum seperti partai politik.

\footnotetext{
${ }^{4}$ https://www.iainpare.ac.id/relasi-partai-politik-dan-korupsi/. Dikses pada 2 November 2020.

5 Asep N. Mulyana, Pendekatan Ekonomi Dalam Penegakan Hukum Terbadap Kejahatan Korporasi, PT. Grasindo, Jakarta, 2018, hlm. xvi.
} 


\section{Metode Penelitian}

Penelitian ini mengunakan penilitian yuridis normatif dengan menggunakan pendekatan perundang-undangan. Penelitian ini mengkaji peraturan perundang-undangan yang berkaitan dengan pidana pengganti serta peran dari teori vicarius criminal liability dalam penanganan kasus pidana yang dilakukan oleh korporasi. Metode pendekatan kualitatif, dengan melakukan studi pustaka dilakukan untuk mengumpulkan data sekunder, berupa peraturan perundang-undangan terkait pertanggungjawaban pidana korporasi. Selain itu, data sekunder juga berupa ulasan atau pendapat para pakar yang terdapat dalam buku, karya tulis ilmiah, dan jurnal, juga melalui internet.

\section{Hasil Penelitian dan Pembahasan}

\section{Kedudukan Partai Politik sebagai Badan Hukum Privat}

Perbedaan teori badan hukum berupa teori fiksi dengan teori organ juga berpengaruh terhadap masalah pertanggungjawaban pidana dari sebuah badan hukum. Berbeda dengan teori fiksi, maka ajaran dari teori organ menganggap badan hukum sebagai benar-benar ada secara riil, sama seperti manusia individual, sehingga tanggungjawabnya pun termaksud tanggung jawab pidana, mestinya juga sama dengan tanggungjawab pidana dari manusia individual. Akan tetapi, terlepas dari teori apapun yang dianut, dalam kenyataannya, terdapat kencenderungan yang kuat secara universal untuk membebankan tanggungjawab pidana terhadap badan hukum yang kurang lebih sama dengan tanggungjawab pidana bagi individual. 6 "

Dalam Pasal 3 Undang-Undang Nomor 2 Tahun 2011 tentang Partai Politik, menyebutkan mengenai keberadaan dan status dari partai politik harus memiliki:

(1)Partai politik harus didaftarkan ke kementrian untuk menjadi badan hukum.

(2)Untuk menjadi badan hukum sebagaiman dimaksud pada ayat (1), partai politik harus mempunyai;

a. Akta notaris pendirian partai politik

b. Nama, lambang, atau tanda gambar yang tidak mempunyai persamaan pada pokoknya atau keseluruhannya dengan nama, lambang, atau tanda gambar yang telah dipakai secara sah oleh partai politik lain sesuai dengan peraturan perundang-undangan;

c. Kepengurusan pada setiap provinsi dan paling sedikit $75 \%$ (Tujuh puluh lima persen) dari jumlah kabupaten/kota pada provinsi yang

${ }^{6}$ Munir Fuady, Teori-Teori Besar Dalam Hukum (Grand Teory), Kencana Pernadamedia Group, Jakarta, 2014, hlm. 204. 
bersangkutan dan paling sedikit 50\% (lima puluh persen) dari jumlah kecamatan pada kabupaten/kota yang bersangkutan;

d. kantor tetap pada tigkat pusat, provinsi, dan kabupaten/kota sampai tahapan terakhir pemilihan umum; dan

e. Rekening atas nama partai politik.

Partai politik sebagai badan hukum dapat dibuktikan berdasarkan Akta Pendirian Partai Politik yang didalamnya tercantum Anggaran Dasar dan Anggaran Rumah Tangga serta kepengurusan dari partai politik. Sebagaimana terlihat dalam Pasal 2 ayat (3) dan ayat (4) Undang-Undang Nomor 2 Tahun 2008 sebagaiman yang telah diubah dengan Undang-Undang No 2 Tahun 2011 tentang Partai Politik, yakni:

(3)Akta notaris sebagaimana dimaksud pada ayat (1) harus memuat AD dan ART serta kepengurusan partai politik tingkat pusat.

(4)AD sebagaian dimaksud pada ayat (3) memuat paling sedikit:

a. Asas dan ciri partai politik;

b. Visi dan misi partai politik;

c. Nama, lambang, dan tanda gambar partai politik;

d. Tujuan dan fungsi partai politik;

e. Organisasi, tempat kedudukan, dan pengambilan keputusan;

f. Kepengurusan partai politik;

g. Peraturan dan keputusan paratai politik;

h. Pendidikan politik; dan

i. Keuangan partai politik.

Partai politik sebagai badan hukum yang disahkan oleh negara masih sulit untuk dilihat dan diraba (invicibel and intangible). Akan tetapi eksistensinya riil dan terpisah (separate) dan bebas (independent) dari subjek hukum person alamiah ataupun dari pengurus dari partai politik. Kedudukan ini menyebabkan partai politik melalui pengurus atau organnya dapat melakukan perbuatan hukum (rechtshandeling) seperti halnya melakukan kegiatan untuk dan atas nama partai politik membuat perjanjian, melakukan transaksi, menggugat dan digugat dipengadilan, namun tidak bisa dipenjarakan, akan tetapi dapat di jadikan sebagai subjek hukum pidana dalam hukuman pidana pengganti. ${ }^{7}$

Dalam negara demokrasi partai politik merupakan hal penting dalam kehidupan berbangsa dan bernegara mengingat negara demokrasi memang di

7 Wahyu, "Pertanggungjawaban Pidana Partai Politik yang Melakukan Tindak Pidana", Jurnal Arena Hukum, Vol 7, Nomor 2, Agustus 2014, hlm. 57 
bangun di atas sistem kepartaian. ${ }^{8}$ Partai politik merupakan badan hukum yang memiliki status dan pengaturan yang berbeda dengan bentuk badan hukum (juristic person) lain. ${ }^{9}$ Kedudukan badan hukum, sebagai suatu organisasi privat maupun secara khusus sebagai badan hukum politik (partial legal order) diberikan oleh hukum negara (total legal order). ${ }^{10}$ Partai politik semakin eksis secara hukum pada saat menerima status sebagai badan hukum baik karena mekanisme pembuatan maupun setelah melalui prosedur hukum tertentu pada saat setelah menjadi badan hukum.

\section{Peran Vicarious Liability dalam Pemidanaan Badan Hukum Partai Politik}

Mahrus Ali dan Hanafi Amrani dalam bukunya yang berjudul "Sistem Pertanggung Jawaban Pidana Perkembangan dan Penerapan", menjelaskan mengenai pengertian Vicarious Liability Oleh para ahli diantaranya:11

a. Peter Gillies memberi pengertian bahwa:

Pertanggungjawaban pengganti adalah pengenaan pertanggunjawaban pidana terhadap seseorang berdasarkan atas perbuatan pidana yang dilakukan oleh orang lain, atau berdasarkan atas kesalahan orang lain, atau berkenaan dengan kedua masalah tersebut.

b. La-Fave berpendapat bahwa:

Pertaggungjawaban penganti adalah suatu dimana seseorang, tanpa kesalahan pribadi bertanggungjawab atas indakan orang lain.

c. Smith \& Brian Hogan menjelaskan:

Secara umum majikan dapat dipertanggungjawabkan atas kesalah yang dilakukan pegawainya, kecuali terhadap ganguan umum dan fitnah atas pencemaran nama baik, maka majikan dipertanggungjawabkan atas tindakan pegawainya meskipun majikan tidak bersalah sama sekali.

d. Menurut Henry Compbell:

Pertanggungjawaban penganti adalah ertanggungjawaban hukum secara tidak langsung, pertanggungjawaban majikan atas tindakan dari pekerja; atau pertanggungjawaban principal terhadap tindakan agen dalam suatu kontrak.

Dari beberapa definisi yang dikemukakan tersebut di atas dapat disimpulkan bahwa vicarious liability adalah pertanggung jawaban menurut hukum seseorang atas perbuatan salah yang dilakukan oleh orang lain. Kedua orang tersebut harus mempunyai 'hubungan atasan dan bawahan' atau

${ }^{8}$ Muchamad Ali Safa'at, Pembaharuan Partai Politik. (Pengaturan Dan Praktik Pembubaran Partai Politik Dalam Pergulatan Republik, PT. RajaGrafindo Persada, Jakarta, 2011, hlm. 3.

${ }^{9}$ Hans Kelsen, General Theory of Law and State, Translet by Andreas Wedberg, Russel \&Russel, New Your, 1961, hlm. 98, Ibid., hlm. 71.

${ }^{10}$ Hans Kelsen, Pure Theory Of Law, Translation from the secong (Revised and Entarged) German Edition by Max Knight, Barkley, Los Angels, University of California Press, London, 1967, hlm. 190-191.

${ }^{11}$ Hanafi Amrani dan Mahrus Ali, Sistem Pertanggungjawaban Pidana Perkembangan dan Penerapan, Rajawali Pers, Jakarta, 2015, hlm. 132. 
'hubungan majikan dan buruh' atau 'hubungan pekerjaan'. Perbuatan yang dilakukan oleh pekerja tersebut harus masih dalam ruang lingkup pekerjaannya. Secara singkat model pertanggungjawaban itu sering disebut 'pertanggungjawaban penganti'. .2

Ada dua syarat penting yang harus dipenuhi untuk dapat menerapkan suatu perbuatan pidana dengan vicarious liability. Syarat-syarat tersebut adalah:

1. Harus terdapat suatu hubungan, seperti hubungan pekerjaan antara majikan dan pegawai atau pekerja.

2. Perbuatan pidana yang dilakukan oleh pekerja atau pegawai tersebut harus berkaitan atau masih dalam ruang lingkup pekerjaannya.

Ryamond dalam buku Sistem Pertanggungjawaban Pidana Perkembangan dan Penerapan menyebutkan, ruang lingkup perbuatan pidana yang dapat diterapkan vicarious liability. Tidak semua perbuatan pegawai merupakan tanggungjawab majikan namun hanya perbuatan yang ada kaitannya dengan majikan. Di samping kedua ketentuan di atas, penerapan vicarious liability berkaitan dengan dua prinsip yaitu prinsip pendelegasian dan prinsip perbuatan buruh merupakan perbuatan majikan.

Asas tiada pidana tanpa kesalahan, atau geen straf zonder schuld, atau keine strafe ohne schuld, atau actus non facit reu nisi mens sir rea, dikenal sebagai salah satu asas penting dalam hukum pidana. Melalui asas ini diperoleh penjelasan bahwa belum tentu ada pertanggungjawaban pidana yang mengikuti adanya suatu tindak pidana yang terjadi. Asas kesalahan atau shuldprinzip ini adalah menyangkut personal guilt dan blameworthinees yang dipersyaratan untuk bisa menentukan parameter bagi pertanggungjawaban pidana dan pemberian hukumnya. Dalam lapangan hukum pidana, dengan keberadaan asas tersebut, maka adanya suatu tindak pidana belum tentu akan diikuti dengan pemberian hukum bagi pelakunya. Bahwa suatu tindak pidana itu hanya menunjuk kepada perbuatan dilarang (dalam pengertian dilakukan secara aktif) atau kepada akibat yang dilarang (dalam pengertian dilakukan secara pasif), dan terhadap pelaku pelanggarnnya diancam dengan suatu pidana; sedangkan apakah akan di berikan sanksi pidana seperti yang telah diancamkan oleh pasal yang dilanggar kepada pelakunya, sangat tergantung dari jawaban, apakah pada diri pelakunya itu ada dan ditemukan unsur kesalahan atau tidak.

Prinsip dari asas tiada pidana tanpa kesalahan ini adalah bahwa orang itu hanya bisa dipidana apabila ia terbukti bersalah melakukan perbuatan yag

12 Ibid., hlm. 133. 
dilarang oleh undang-undang. Kesengajaannya bisa dalam bentuk kesengajaan ataupun dalam bentuk kelalaian. Dengan demikian, larangan dari suatu aturan pidana itu ditujukan pada suatu perbuatan atau akibat yang muncul, yaitu suatu keadaan atau kejadian yang ditimbulkan oleh tindakan orang, sedangkan ancaman pidannya ditujukan kepada orang yang menimbulkan kejadian itu:13

1. Prinsip pertanggungjawaban berdasarkan atas adanya unsur kesalahan (fault liability, liability based on fault principle). Prinsip ini membebankan kepada korban untuk membuktikan bahwa pelaku itu telah melakukan perbuatan melaan hukum yang merugikan dirinya.

2. Prinsip tanggungjawab berdasarkan adanya praduga (rebuttable presumption of liability principle). Prinsip ini menegaskan bahwa tanggung jawab si pelaku bisa hilang jika dapat membuktikan tidak bersalah kepada orang lain.

3. Prinsip tanggungjawab mutlak (no-fault liability, absolute atau strict liability principel), yaitu tanggungjawab tanpa harus membuktikan kesalahan.

Berkaitan dengan pertanggungjawaban partai politik sebagai badan hukum privat dapat dilakukan pendekatan melalui teori-teori berikut. Pertama, teori pelaku fungsional (fungtioneel daaderschap) yang menunjuk bahwa pidana dilakukan oleh orang yang memiliki hubungan kerja dengan partai politik sepanjang masih dalam ruang Anggaran Dasar dan Anggaran Rumah Tangga yang diatur dalam partai politik. Kedua, Teori Identifikasi bahwa partai politik dapat melakukan pidana secara langsung melalui orang-orang yang memiliki hubungan sangat erat dengan partai politik atau dipandang sebagai partai politik itu sendiri. Ketiga, teori vicarious liability. Teori employment principle, yakni majikan adalah penanggungjawab utama dari perbuatan buruh/karyawan. Partai politik adalah penanggungjawab utama dari perbuatan anggota dan kadernya. Keempat, teori strict liability. Partai politik dianggap bertanggungjawab apabila melanggar perintah peraturan perundang-undangan. ${ }^{14}$

Bentuk pertanggungjawaban pidana terhadap partai politik yang mempertimbangkan ajaran tendensi sosiologis adalah pidana denda. Selain pidana denda, dapat dijatuhkan pula pidana tambahan berupa: a). Pengumuman putusan hakim, b). Pembekuan sebagian atau seluruh kegiatan usaha korporasi, c). Pencabutan izin usaha, d). Pembubaran dan/atau pelarangan korporasi, e). Perampasan aset korporasi untuk negara, dan/atau; f). Pengambilalihan korporasi oleh negara. Namun, dalam hal korporasi tidak mampu membayar pidana denda, diganti dengan perampasan harta kekayaan milik korporasi yang

${ }^{13}$ Hasbullah F. Sjawie, Pertanggungjawaban Pidana Korporasi Pada Tindak Pidana Koropsi, Kencana, Jakarta, 2017, hlm. 7-9

${ }^{14}$ Mahrus Ali, Hukum Pidana Korupsi, UII Press, Yogyakarta, 2016, hlm. 43. 
nilainya sama dengan putusan pidana denda yang dijatuhkan. Jika dalam hal penjualan harta kekayaan milik korporasi yang dirampas tidak mencukupi, pidana kurungan pengganti denda dijatuhkan terhadap personel pengendali korporasi dengan memperhitungkan denda yang telah dibayar. ${ }^{15}$

Mengingat sanksi pidana pokok yang dikenakan terhadap korporasi adalah pidana denda, yang mana jika denda tidak dibayar dalam ketentuan KUHP dinyatakan akan dikenakan pidana kurungan pengganti, yang lamanya 1 hari dan paling lama 6 bulan, sebagaimana yang dirumuskan dalam Pasal 30 KUHP. Tentunya rumusan sanksi ini hanya berlaku manusia sebagai subjek hukum pidana, tidak dapat dijalankan oleh partai politik sebagai badan hukum. Bahkan penerapan sanksi pidana tambahan sangat bergantung pada hakim pengadilan yang menyidangkan perkara tersebut. Jika hakim tidak membuat dalam amar putusannya maka sanksi pidana tersebut tidak mencerminkan rasa keadilan sebagai wujudkan keseimbangan, sosial, ekonomi budaya, politik untuk kemaslahatan bangsa.

Dalam perkembangan ilmu hukum modern saat ini, salah satu bentuk pertanggungjawaban pidana untuk partai politik sebagai badan hukum, adalah doktrin pertanggungjawaban pidana pengganti (vicarious liability). Doktrin ini, pertama kali diperkenalkan di Amerika Serikat dan Inggris, negara-negara dengan sistem hukum common law, yang berasal dari doktrin superior respondeat (vicarious liability), yang juga disebut pertanggungajawaban pidana pengganti. ${ }^{16}$

Adapun doktrin pertanggungjawaban pidana lainnya yang dikenakan pada partai politik yang melakukan tindak pidana korupsi serta tindak pidana lainnya, yaitu doktrin strict liability. Doktrin ini sering disebut dengan tanggungg jawab ketat atau tanggung jawab mutlak yaitu pertanggungjawaban hukum tidak langsung. Pertanggungjawaban majikan atas tindakan dari pekerja atau pertanggungjawaban prinsipil terhadap tindakan dalam suatu kontrak (strict liability) tidak membutuhkan mens rea. Mens rea tetap dianggap ada tetapi tidak perlu dibuktikan, cukup actus reus. ${ }^{17}$

Persoalan pertanggungjawaban pidana terhadap partai politik sebenarnya tidak terlepas dari ketentuan Umum Hukum Pidana, yaitu Buku ke 1 Kitab Undang-Undang Hukum Pidana (yang selanjutnya disebut KUHP) yang hanya

${ }^{15}$ Maria Silvya E. Wangga, "PertanggungJawaban Pidana Partai Politik Sebagai Badan Hukum dalam Tindak Pidana Korupsi”, Jurnal Integritas, Volume 4 Nomor 2, Desember 2018, hlm. 271.

16 Marsavelski, Alexander, Responibility of Political Parties foCriminal Offences: Preliminary Observations, vChallengesvandControversies,https://papers.ssrn.com/sol3/papers.vcfm?abstract_id=2610306\& download=yes, diakses 4 Maret 2018, hlm. 7

${ }^{17}$ Hanafi Amrani dan Mahrus Ali, Sistem Pertanggungjawaban ..., Op. Cit., hlm. 133-134. 
mengenal orang perseorangan yang menjadi pelaku tindak pidana belum diatur secara jelas. Alasan dari belum diaturnya badan hukum sebagai sujek tindak pidana, karena pembuat undang-undang berpegang teguh pada prinsip bahwa suatu tindak pidana hanya dapat dilakukan oleh person alamiah dan menerima adagium "societas delinquere non potest" (kesatuan hukum atau perhimpunan tidak dapat melakukan tindak pidana). ${ }^{18}$

Untuk mengatasi keraguan mekanisme dalam penegakan pertanggungjawaban badan hukum, Mahkamah Agung menetapkan peraturan Mahkamah Agung Republik Indonesia Nomor 13 Tahun 2016 tentang Tata Cara Penaganan Perkara Tindak Pidana oleh Korporasi. Adanya pengaturan pertanggungjawaban pidana terhadap badan hukum merupakan langkahlangkah dalam penegakan hukum yang dapat diberlakukan terhadap partai politik, sebagai konsekuensi yuridis yang telah disetujui bersama dan diyakni bersifat netral, tidak berpihak dan objektif. ${ }^{19}$ Sebagaimana dalam rumusan Pasal 4 berikut ini:

(1): "korporasi dapat dimintakan pertanggungjawaban pidana sesuai dengan ketentuan pidana korporasi dalam undang-undang yang mengatur tentang Korporasi".

(2): "dalam menjatuhkan pidana terhadap korporasi, hakim dapat menilai kesalahan korporasi sebagai mana ayat (1) antara lain:

a. Korporasi dapat memperoleh keuntungan atau manfaat dari tindakan pidana korupsi tersebut atau tindak pidana tersebut dilakukan untuk kepentingan korporasi;

b. Korporasi membiarkan terjadinya tindak pidana atau;

c. Korporasi tidak melakukan langkah-langkah yang diperlukan untuk melakukan pencegahan, mencegah dampak yang lebih besar memastika kepatuhan terhadap ketentuan hukum yang berlaku guna menghindari terjadinya tindak pidana.

Meskipun telah dibuat formulasi norma hukum, dalam aplikasi penegakan hukum, tampaknya berjalan ditempat karena tidak ada satupun partai politik yang dapat dipertanggungjawabkan sebagai badan hukum tindak pidana korupsi. Penegak hukum berpandangan bahwa perbuatan tindak pidana korupsi yang dilakukan oleh pengurus partai politik tetap merupakan pertanggungjawaban individu, belum dapat dikenakan ke partai politik karena

${ }_{18}$ Mutadi, Hak Asasi Manusia dan Reformasi Hukumdi Indonesia, The Habibie Center, Jakarta, 2002, hlm. 157.

19 Adji, FX, Samekto, "Keterkaitan Kapitalisme dengan Konsep Pembangunan Berkelanjutan dan Implementasi Konvensi Keanekaragaman Hayati dalam Kajian Studi Hukum Kritis (Critical Legal Studies)", ringkasan Disertasi untuk memperoleh Pertanggungjawaban Pidana Partai Politik sebagai Badan Hukum dalam Tindak Pidana Korupsi 276", Volume 4 Nomor 2, Desember 2018 Gelar Doktor Ilmu Hukum pada program Pascasarjana Universitas Diponegoro, Program Doktor Ilmu Hukum Program Pascasarjana Universitas Diponegoro, Semarang, 2004, hlm. 2. 
bukan kebijakan partai. Jika demikian proses pencarian kebenaran dan keadilan tidak tercapai, karena tataran praktiknya lebih pada hal-hal prosedural.

Korupsi memiliki banyak bentuk, namun dua bentuk utamanya adalah: pertama, korupsi administrasi yang berarti proses korupsi dilakukan dengan tingkat ketertiban administrasi, sehingga secara administrasi atau hukum, tindakan tersebt seolah-olah bukan korupsi; dan kedua, korupsi yang sepenuhnya bertentangan dengan hukum. ${ }^{20}$ Klasifikasi ini merupakan salah satu upaya pengelompokan berdasarkan praktik korupsi yang berlangsung secara empiris.

Adanya formulasi norma yang telah mengatur bentuk pertanggungjawaban pidana terhadap partai politik selaku badan hukum, penulis berpandangan untuk segera mengesahkan RUU KUHP agar dapat memperkuat penegakan hukum atas partai politik dalam tindak pidana korupsi di masa mendatang. Mengingat formulasi norma bentuk pertanggungjawaban pidana terhadap partai politik, selaku korporasi, telah diatur pula dalam Peraturan Mahkamah Agung RI Nomor 13 Tahun 2016 tentang Tata Cara Penanganan Perkara Tindak Pidana Oleh korporasi, Undang-Undang Nomor 31 Tahun 1999 tentang Pemberantasan Tindak Pidana Korupsi maupun Undang-Undang Nomor 8 Tahun 2010 tentang Pencegahan dan Pemberantasan Tindak Pidana Pencuciaan Uang.

\section{Penutup}

Berdasarkan uraian di atas, maka penulis mengambil kesimpulan bahwa pertama, partai politik merupakan badan hukum sehingga termasuk dalam subjek hukum privat. Kedua, vacirious liability berperan dalam upaya pemidanaan badan hukum seperti Partai Politik berupa pidana denda atau tambahan, yang mana dalam tataran praktik mendapatkan kesulitan atau kelemahan.

Saran yang diberikan adalah medorong aparat penegak hukum dalam hal ini hakim yang sebagai penegak hukum dalam memutuskan setiap kasus yang berkaitan dengan korporasi (partai politik) dalam setiap pelanggaran yang terjadi maka Hakim harus lebih berani dalam memberikan putusan kepada korporasi yang melakukan pelanggaran terhadap hak asasi manusia. Dalam proses penegakan hukum harus lebih kuat lagi dalam perlindungan kepada korban hak asasi manusia atas pelangaran yang dilakukan oleh partai politik. Penegak hukum harus berani dalam mengambil keputusan pembubaran partai politik dalam hal secara pembuktian bahwa telah terjadi pelangaran hukum yang serius di dalam masyarakat.

${ }^{20}$ Darwan Prinst, Pemberantasan Tindak Pidana Korupsi, PT. Citra Aditya Bakti, Bandung, 2002, hlm. 16-17. 


\section{Daftar Pustaka}

\section{Buku}

Ali, Mahrus, Hukum Pidana Korupsi, UII Press, Yogyakarta, 2016. Isu-Isu Kontemporer Hukum Pidana, UII Press, Yogyakarta, 2019.

Amrani, Hanafi dan Mahrus Ali, Sistem Pertanggungjawaban Pidana Perkembngan dan penerapan, Raja Grafindo Persada, Jakarta, 2015.

Kelsen, Hans, General Theory of Law and State, Translet by Andreas Wedberg. New Your : Russel \&Russel, 1961,.

Pure Theory Of Law, Translation from the Secong (Revised and Entarged) , German Edition by Max Knight, Barkley, Los Angels, University of California Press, London, 1967.

Koechlin, Lucy, an Evaluation of National Integrity System (NIS) From a Human Rights Perspeective, nternasional Council on Human Ribht Policy, 2018.

Ladman, Todd, \& Carl Jan Wlliem Scuhdel, Corporation and Human Rights: Empirical Relationship and Policy Advice, The Internasional Coucil on Human Right Policy, 2007.

Mutadi, Hak Asasi Manusia dan Reformasi Hukumdi Indonesia, The Habibie Center, Jakarta, 2002.

Prinst, Darwan, Pemberantasan Tindak Pidana Korupsi, PT.Citra Aditya Bakti, Bandung, 2002.

Riyadi, Eko, dkk., Korupsi Sebagai Pelanggaran Hak Asasi Manusia Tawaran Prespektif, PUSHAM UII, Yogyakarat, 2019.

Safa'at, Muchamad Ali. Pembaharuan Partai Politik (Pengaturan Dan Praktik Pembubaran Partai Politik Dalam Pergulatan Republik, PT. RajaGrafindo Persada, Jakarta, 2011.

\section{Jurnal dan Disertasi}

Adji, FX, Samekto, Keterkaitan Kapitalisme dengan Konsep Pembangunan Berkelanjutan dan Implementasi Konvensi Keanekaragaman Hayati dalam Kajian Studi Hukum Kritis (Critical Legal Studies), ringkasan Disertasi untuk memperoleh Pertanggungjawaban Pidana Partai Politik sebagai Badan Hukum dalam Tindak Pidana Korupsi 276, Volume 4 Nomor 2, Desember 2018 Gelar Doktor Ilmu Hukum pada program Pascasarjana Universitas Diponegoro, Program Doktor Ilmu Hukum Program Pascasarjana Universitas Diponegoro, semarang, 2004.

Maria Silvya E. Wangga, PertanggungJawaban Pidana Partai Politik Sebagai Badan Hukum dalam Tindak Pidana Korupsi, Jurnal Integritas, Volume 4 Nomor 2, Desember 2018.

Wahyu, "Pertanggungjawaban Pidana Partai Politik yang Melakukan Tindak Pidana", Jurnal Arena Hukum, Vol 7, Nomor 2, Agustus 2014. 


\section{Website}

https:/ / sport.tempo.co/read/1367427/kpk-beri-lampu-hijau-pembangunanhambalang-dilanjutkan-tapi diakses pada tanggal 21 agustus 2020.

Marsavelski, Alexander, Responibility of Political Parties foCriminal Offences: Preliminary

Observations,vChallengesvandControversies,https:/ / papers.ssrn.com/so 13/papers.vcfm?abstract_id=2610306\&download=yes, diakses pada 21 agustus 2020. 